\title{
Retinal Blood Vessel Segmentation as a Tool to Detect Diabetic Retinopathy
}

\author{
Dhimas Arief Dharmawan ${ }^{1}$, Latifah Listyalina*2 \\ ${ }^{1}$ Department of Electrical Engineering, Faculty of Engineering, Universitas Muhammadiyah Yogyakarta \\ Jalan Brawijaya, Geblagan, Tamantirto, Kasihan, Bantul 55183, Telp (0274) 387656 \\ ${ }^{2}$ Department of Electrical Engineering, Faculty of Science and Technology, Universitas Respati Yogyakarta \\ Jalan Laksda Adisucipto Km 6.3, Sleman 55281, Telp (0274) 488781 \\ *Corresponding author, e-mail: listyalina@respati.ac.id
}

\begin{abstract}
The retina is an important part of the eye for humans. In besides its main function as part of the sense of sight, in the world medically, the retina after an image can be used to detect a number diseases, such as diabetic retinopathy. To detect a number of diseases, Retinal digital images taken using a digital fundus camera are used. In detecting diabetic retinopathy, digital images are needed segmented retina. Nevertheless, automatic segmentation of digital images the retina is a complex work, given the presence of artifacts as well as noise on the retinal digital image, evenly illuminated, intensity low, low contrast, and varying lengths of retinal blood vessels. In this research, a blood vessel segmentation software system has been designed through three stages image processing, namely (i) preprocessing, (ii) improving image quality, (iii) and segmentation of retinal blood vessels. With three image processing stages, the performance value is obtained, i.e. 84.62 .
\end{abstract}

Keywords: Retina, Vessel, Diabetic, Segmentation

\section{Introduction}

The retina is an important part of the eye for humans. On humans, the retina functions to receive focused light from the lens, change it into the form of certain signals, and then send these signals to the brain through neural networks (Qin-Li, 2010). Besides its main function, in the medical world, the retina after imaging is also used to detect a number of diseases, such as diabetic retinopathy, hypertension, and glaucoma (Nandy and Banerjee, 2012).

To detect a number of diseases, digital images of the retina are used taken using a digital fundus camera. In detecting on a number of diseases, especially diabetic retinopathy and hypertension, are needed segmented retinal digital image. In the past few decades, automatic segmentation of retinal digital images with the help of computers became a popular thing (Tavakoli, 2010).

Nevertheless, segmentation automatically retinal digital image is a complex work, given the presence of artifacts and noise in the retinal digital image, the illuminations are uneven, dark intensity, low contrast, and long blood vessels various retinas (Fraz et al, 2011).

Several studies have been conducted to segment retinal blood vessels. One of them is a study conducted by Bob Zhang et al (2010) using a matched filter with the first derivative of gaussian as the method. The study was $93.82 \%$ accuracy. Similar studies were also carried out by Fraz et al (2011) using multiscale line strength, gabor filters and morphological features as the method, and gave an accuracy of $94.76 \%$. Better results in a similar study of $96.16 \%$ accuracy were obtained by Nandy and Banerjee (2012) who used gabor filters and artificial neural networks as the method. Further research on segmentation and analysis of FAZ for the classification of diabetic retinopathy has been carried out by Fadzil et al (2011) with independent component analysis (ICA) as the method and produces a sensitivity of $90.81 \%$, specificity 
98.29\% and accuracy of $97.46 \%$.

In this research, a software for the effort will be designed segmentation of blood vessels in the retinal digital image for the detection of diabetic retinopathy. Matched filters are used to segment retinal blood vessels. It is expected to get an output in the form of blood vessel segmentation as well value of sensitivity, specificity, and accuracy. In addition, results vessel segmentation in this study can be used for detection of diabetic retinopathy.

\section{Basic Theory}

\section{II.1. Eye}

The eye is one of the senses, precisely the sense of sight. Eye capture information from the surrounding environment in the form of light for later analysis and interpretation. The process of visual perception involves systems with complex structures, where each of the constituent components of the eye has their respective functions. One of the components of the human eye is the retina (Remington, 2012).

The retina is a sensitive layer of the eye and functions to receive images that have been converted by the lens into brain signals, and transmit these signals to the brain through the optic nerves. The retina functions like a film on a camera. The shape of the cross section of the human eye and its retina can be seen in Figure 2.1 (Hikmah, 2008).

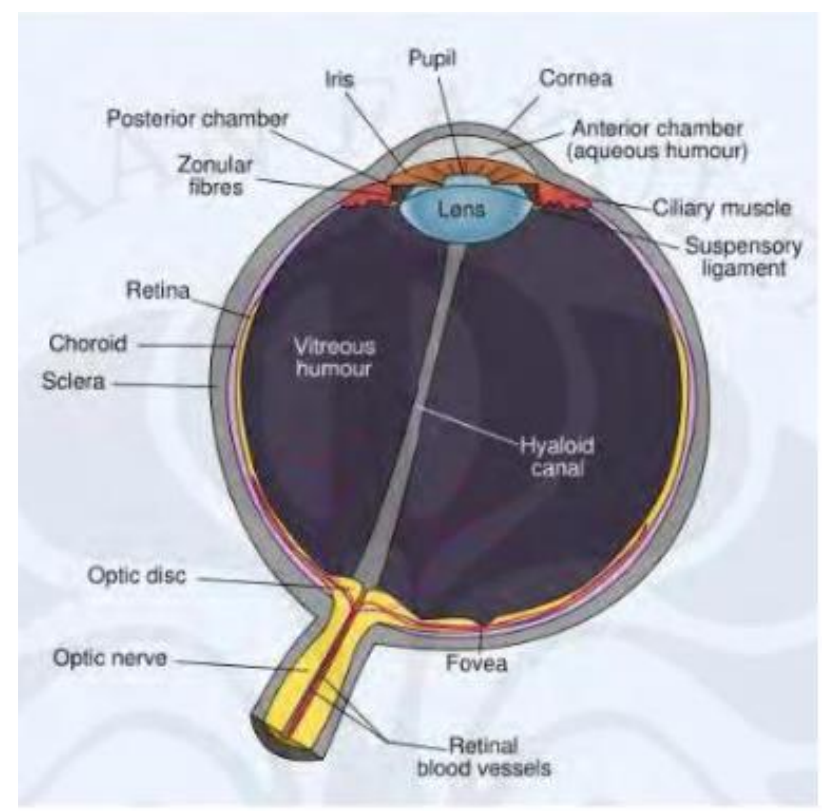

Fig. 1. Eye (Hikmah, 2008)

\section{II.2. Diabetic Retinopathy}

Diabetes mellitus (DM) is the most common degenerative chronic disease with high morbidity and mortality rates in the world. World Health Organization (WHO) reports that Indonesia ranks fourth, the country with the highest number of people with DM. This number will reach 21.3 million in 2030 (Sitompul, 2011).

According to Rema and Pradeepa (2007), diabetic retinopathy (DR) is a blood vessel disorder that attacks the retinal microvascular. It is estimated, that diabetes mellitus accounts for half of the many sufferers of DR. DR is suffered by both people with type I and II diabetes mellitus. According to epidomological studies, almost all people with type I diabetes mellitus suffer from DR, and about $75 \%$ of patients with type II diabetes mellitus also suffer from DR.

\section{II.3. Multiscale Top Hat Transformation}

According to Liao (2014), top-hat transformation operations are divided into two transformation operations, namely white top-hat transformation (WTH (x, y)) operations, and black top-hat transformation (BTH $(\mathrm{x}, \mathrm{y})$ ) operations. The two transformation operations can be formulated by equations (2.5) and (2.6) (Liao, 2014).

$$
\begin{gathered}
W T H(x, y)=f-f \circ b \\
\operatorname{BTH}(x, y)=f \cdot b-f
\end{gathered}
$$

White top-hat transformation is used to extract bright areas, while black top-hat transformation is used to extract dark areas from a grayscale image (Liao, 2014).

\section{II.4. Histogram Fitting Strectching}

Image quality improvement techniques aim at improving quality image both from the human visual side, as well as from the information contained therein. Image quality improvement can be performed point operations, spatial operations, geometry operations and arithmetic operations. One of the four methods above that is easy to do is point surgery, where stretching contrast is included (Putra, 2009).

Contrast stretching is a very useful technique for improve image contrast especially images that have low contrast. Contrast stretching works by transforming the gray degree of the input image 
into a range that tends to be wider using a particular transformation function.

\section{II.5. Matched Filter}

Matched filter is an optimal linear filter designed to detect the presence of a signal in the structure noise that is already known (Wilkinson, 2013). Matched filters work by maximizing the ratio or ratio of signals to noise (SNR) on signals that are detected against noise contained in the structure (Bancroft, 2002).

Generally, retinal digital images have low contrast, so it is difficult to distinguish between blood vessels and other objects. The basic idea of using a matched filter is to take a number of samples at the meeting points of the retinal blood vessels. The gray level of the sample is further approximated by a gaussian curve (Chanwimaluang et al, 2003).

The application of matched filters on retinal digital images is done by convoluting matched kernel filters with retinal digital images to improve the quality of blood vessels in retinal digital images. The matched kernel filter used is defined by the following equation (2.21).

$$
K(x, y)=-\exp \left(\frac{x^{2}}{2 \sigma^{2}}\right),|y| \leq L / 2
$$

Where $\mathrm{L}$ is the length of the segment for a vessel considered to have a fixed orientation on the $y$ axis (Supot et al, 2007).

\section{II.6. Length Filter}

As generally, the filter functions to filter or skip certain cues. This also happened to the length filter. Length filters work by applying certain threshold values to images that have been labeled into certain objects. Objects whose neighbors are less than the threshold value will be minimized. Length filters are usually applied to reduce noise in binary images (Ardizzone, 2008)

\section{Methodology}

The data used in this study were 35 retinal digital images. The data was obtained by downloading a set of retinal digital image data from the official website of Digital Retinal Images for Vessel Extraction (DRIVE). To carry out this research, a laptop device was used Intel Celeron CPU 1007U / 2GB RAM specs. The laptop is equipped with MATLAB R2013a as the main application to carry out this research.

From the results of retinal digital images obtained, done image processing in order to obtain the desired image, namely FAZ. The steps of retinal digital image processing are as following. First, the preprocessing step is done green channel and cropping each retinal digital image. Second, the stages of image quality improvement consist of multiscale top-hat transformation and histogram fitting stretching. Third, retinal segmentation is performed using matched filters and length filters.

\section{Result and Discussion}

\section{A.Preprocessing}

At this preprocessing stage, two operations are carried out, namely taking green channels on the retinal digital image and cropping. Both operations are carried out to obtain the appropriate part of the image this research needs.

Intake of the green channel on the retinal digital image aims to create an image that only has one channel value per each the pixel. The original retinal digital image has the RGB format, where each channel is represented by a specific matrix as explained in the previous review. For this reason, it is enough to take green canals by taking a matrix that represents only green canals. Likewise in taking red and blue channels.

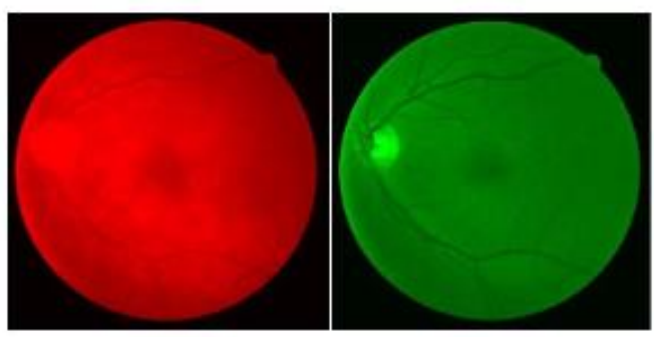

(a)

(b)

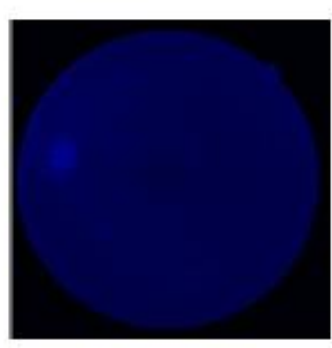

(c)

Fig. 2. Red (a), green (b), and blue (c) channel images 
It appears that the image of the green channel has the best contrast and illumination compared to the other two channels, so it can be distinguished between blood vessels and background. That way, the process of segmenting blood vessels in canal images green can be done to the maximum.

The cropping process is done automatically using Matlab 2013a software. Initial image of the retina, which is $565 \times 584$ pixels, is cut to $200 \times 200$ pixels.
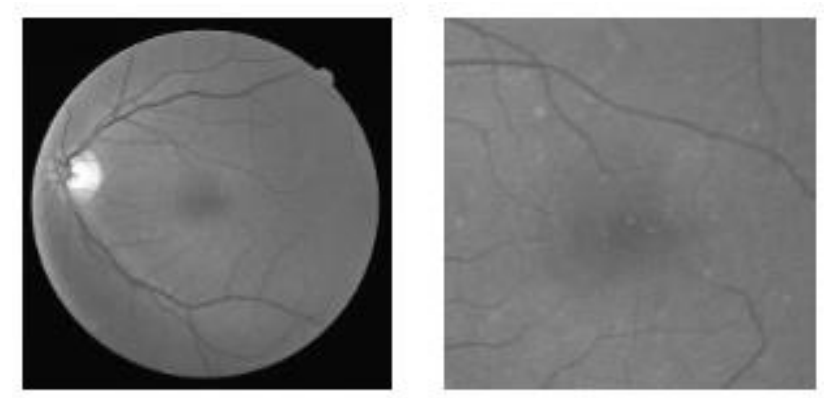

Fig. 3. Digital retinal images before cropping (left) and after cropping (right)

From the picture above, it appears that the cropping stage removes the black frame of the retinal digital image. The area was chosen because to be able to detect diabetic retinopathy, an area of Fovea Avascular Zone (FAZ) is needed (Fadzil, 2011).

\section{B. Image Quality Enhancement}

The image enhancement stage is divided into two, namely multiscale top-hat transformation and histogram fitting stretching.
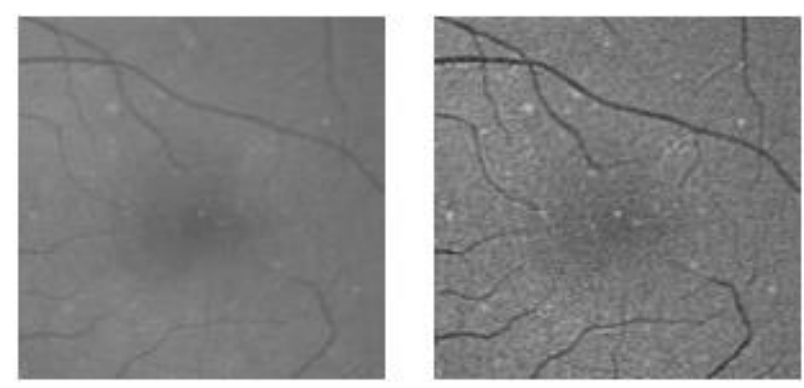

Fig. 4. Images before (left) and after (right) multiscale top-hat transformation operation

Iit appears that the image of the multiscale tophat transformation operation has a higher contrast than the image before the multiscale top-hat transformation operation. Thus, the difference between blood vessels and the background is increasingly clear. The image of the results of the multiscale top-hat transformation operation becomes input at the histogram fitting stretching stage.
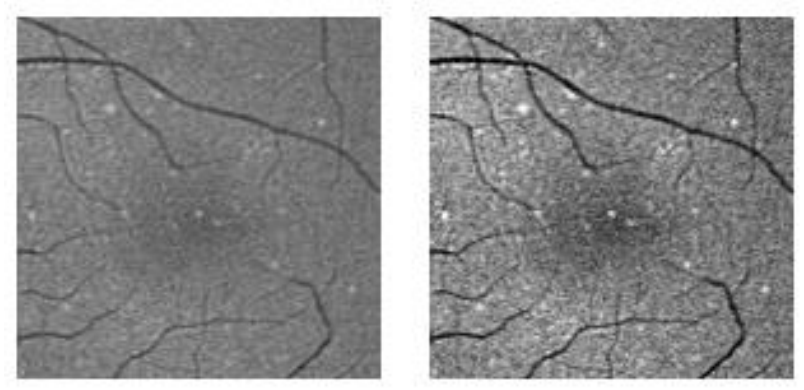

Fig. 5. Images before (left) and after (right) histogram fitting stretching operation

This is evidenced by the increasingly clear differences between blood vessels and background. Along with the increased contrast, the process of segmentation of blood vessels in the later stages can run optimally.

\section{Vessel Segmentation}

In this study, retinal blood segmentation was implemented using matched filters. In the operation of a matched filter the kernel is needed. The following is an example of the image of the results of retinal blood segmentation with matched filters.

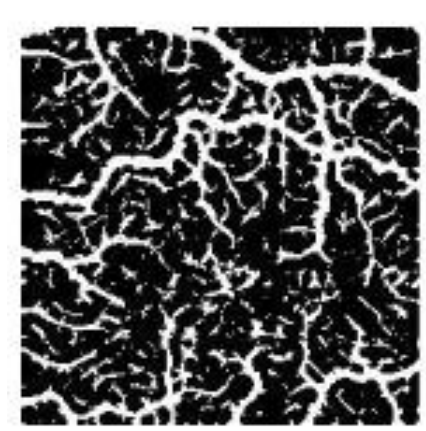

Fig. 6. Example of segmentation retinal blood vessel result

Referring back to the Figure above, it appears that there are non segmented blood vessels. This can be categorized as noise. To overcome this, a length filter is used. The length filter operates by applying a certain threshold value $(\mathrm{N})$, so that noise with a pixel count less than the $\mathrm{N}$ value will be eliminated.

From the table below, an average accuracy of 84.62 is obtained. this indicates that blood vessel segmentation has been successfully performed. 
TABLE I

ACCuRACy of Retinal Vessel SEgmentation Results

\begin{tabular}{cc}
\hline \hline 1 & 86.39 \\
2 & 82.73 \\
3 & 79.13 \\
5 & 85.22 \\
6 & 84.27 \\
7 & 90.05 \\
8 & 83.82 \\
9 & 86.25 \\
10 & 85.28 \\
11 & 84.11 \\
12 & 83.02 \\
13 & 83.81 \\
14 & 78.81 \\
16 & 83.88 \\
17 & 83.75 \\
18 & 85.16 \\
19 & 84.57 \\
20 & 87.48 \\
21 & 81.04 \\
22 & 84.59 \\
24 & 81.69 \\
25 & 84.75 \\
26 & 86.63 \\
27 & 82.69 \\
28 & 86.45 \\
29 & 86.17 \\
30 & 85.65 \\
32 & 83.18 \\
33 & 82.95 \\
35 & 88.82 \\
36 & 84.94 \\
37 & 86.93 \\
38 & 86.69 \\
39 & 86.39 \\
40 & 84.41 \\
\hline & \\
& \\
\hline
\end{tabular}

\section{Conclusion}

A successful foveal avascular zone (FAZ) segmentation software system has been designed on the retinal digital image. The system consists of three stages of image processing, namely (i) preprocessing, (ii) enhancement of image quality, (iii) retinal vein segmentation. From the results of system testing, obtained an average high accuracy, which is equal to $84.67 \%$.

\section{References}

[1] Al-Rawi, M., Qutaishat, M., and Arrar, M. 2007. An improved matched filter for blood vessel detection of digital retinal images. Computers in Biology and Medicine, Science Direct. 37: 262-267.

[2] Ardizzone, E., Pirrone, R., Gambino, O., Radosta, S. 2008. Blood Vessels and Feature Points Detection on Retinal Images. Annual International IEEE EMBS Conference. Hal. 2246-2249.
[3] Bancroft, J. C. 2002. Intorduction to matced filters. Crewes Research Report. Vol 14.

[4] Chanda, B., and Majumder, D. D. 2006, Digital Image Processing and Analysis. Prentice Hall of India, New Delhi.

[5] Chanwimaluang, T., Fan, G. 2003. An Efficient Blood Vessel Detection Algorithm for Retinal Images Using Local Entropy Thresholding. Proceedings Of The 2003 IEEE International Symposium On Circuits And systems. 5: 21-24.

[6] Chauduri, S., Chatterjee, S., Katz, N., Nelson, M., and Goldbaum, M. 1989.

[7] Detection of Blood Vessels in Retinal Images Using Two-Dimensional Matched Filters. IEEE Transaction on Medical Imaging. 8(3): 263-269.

[8] Fadzil, M. H. A, Izhar, L.I., Nugroho, M., and Nugroho, H.A. 2011. Analysis of retinal fundus images for grading of diabetic retinopathy severity. International Federation for Medical and Biological Engineering.

[9] Fraz, M. M., Remagnino, P., Hoppe, A., Velastin, S., Uyyanonvara, B., and Barman, S.A. 2011. A Supervised Method for Retinal Blood Vessel Segmentation Using Line Strength, Multiscale Gabor and Morphological Features. IEEE International Conference on Signal and Image Processing Applications (ICSIPA 2011). hal. 410415.

[10] Hikmah, N. 2008. Identifikasi Retina Mata Manusia Menggunakan Sistem Inferensi Neuro Fuzzy Adaptif. Departemen Teknik Elektro, Fakultas Teknik, Universitas Indoneisa, Jakarta.

[11] Hilderbrand, G. D. and Fielder, A. R. 2011. Anatomy and Phisiology of the Retina. Dalam Pediatric Retina. eds. J. Reynolds and S. Olitsky. Springer-Verlag Berlin Heidelberg, Berlin.

[12] Karimah, F. 2012. Implementasi Learning Vector Quantization (LVQ) sebagai Alat Bantu Identifikasi Kelainan Jantung melalui Citra Elektrokardiogram. Program Studi S1 Teknobiomedik, Fakultas Sains dan Teknologi, Universitas Airlangga, Surabaya.

[13] Lantuéjoul, Ch. 1977. Sur le modèle de JohnsonMehl généralisé. Internal report of the Centre de Morph. Math., Fontainebleau.

[14] Liao, M., Zhao, Y., Wang, X., and Dai, P. 2014. Retinal vessel enhancement based on multi-scale top-hat transformation and histogram fitting stretching. Optics \& Laser Techology, Science Direct. 58: 56-62.

[15] Listyalina, L. 2013. Implementasi Learning Vector Quantization (LVQ) untuk Klasifikasi Kanker Paru dari Citra Rontgen. Program Studi S1 Teknobiomedik, Fakultas Sains dan Teknologi, Universitas Airlangga, Surabaya.

[16] Lubis, R. R. 2007. Diabetik Retinopati. Departemen Ilmu penyakit Mata, Fakultas Kedokteran Universitas Sumatera Utara, Medan. 
[17] Mansson, M., Brautaset, R., Ramsay, M. W., and Nilsson, M. 2012. Fundus autofluorescence with the Canon CR-2 PLUS. International Journal of Ophthalmic Practice. 3(5): 204-212.

[18] Nandy, M., and Banerjee, M. 2012. Retinal Vessel Segmentation Using Gabor Filter and Neural Network. IEEE, 2012 Third International Conference on Emerging Applications of Information Technology (EAIT). hal. 157-160.

[19] Prasetyo, E. 2011. Pengolahan Citra Digital dan Aplikasinya menggunakan Matlab. Penerbit Andi, Yogyakarta.

[20] Pratt, W. K. 2007. Digital Image Processing. WILEY-INTERSCIENCE, Wiley \& Sons, Inc, New Jersey.

[21] Putra, D. 2009. Pengolahan Citra Digital. Penerbit Andi, Yogyakarta.

[22] Qin-Li, 2010, Colour Retinal Image Segmentation For Computer-Aided Fundus Diagnosis. The Hong Kong Polytechnic University Department of Computing, Hongkong.

[23] Rahma, O., N. 2013. Implementasi Jaringan Saraf Tiruan Sebagai Alat Bantu Identifikasi Anemia pada Citra Sel Darah Merah. Program Studi S1 Teknobiomedik, Fakultas Sains dan Teknologi, Universitas Airlangga, Surabaya.

[24] Rema, M., and Pradeepa, R. 2007. Diabetic retinopathy: An Indian perspective. Indian $\mathrm{J}$ Med Res 125, March 2007. hal. 297-310.

[25] Remington, L. A. 2012. Clinical Aanatomy and Phisiology of The Visual System. Elsevier, Missouri.

[26] Saine, P. J. 1992. Focusing The Fundus Camera: A Clinical Approach. Journal of Ophthalmic Photography. 14(1): 7-24.

[27] Sitompul, R. 2011. Retinopati Diabetik. J Indon Med Assoc. 61(8): 337-41.

[28] Shih, F. Y. 2009. Image Processing and Mathemathical Morphology, Fundamentals and Applications. CRC Press, Boca Raton.

[29] Supot, S., Thanapong, C., Chuchart, P., and Munas, S. 2007. Automatic Segmentation of Blood Vessels in Retinal Image Based on Fuzzy KMedian Clustering. Procedings of the 2007 IEEE International Conference on Integration Technology. hal. 584-588.

[30] Susilawati, I. 2009. Teknik Pengolahan Citra. Universitas Mercu Buana, Yogyakarta.

[31] Tavakoli, H. R., Pourreza, R., and Quchani, S. R. 2010. Study of Gabor and Local Binary Patterns for Retinal Image Analysis. Procedings of the 2007 IEEE Third International Workshop on Advanced Computational Intelegence. hal. 527-532.

[32] Wilkinson, A. J. 2013. Matched Filter. Department of Electrical Engineering University of Cape Town, Cape Town.

[33] Wijaya, M., Ch., dan Prijono, A. 2007. Pengolahan Citra Digital Menggunakan MATLAB Image
Processing Toolbox. Penerbit Informatika, Bandung.

[34] Wirayuda, T. A. B. 2006. Pemanfaatan Operasi Morphologi untuk Proses Pendeteksian Sisi pada Pengolahan Citra Digital. Makalah dipresentasikan pada Seminar Nasional Sistem dan Informatika, November 17, Bali.

\section{Authors' information}

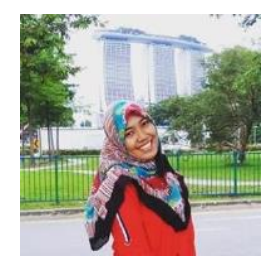

Latifah Listyalina is a lecturer at the Department of Electrical Engineering, Faculty of Science and Technology, Universitas Respati Yogyakarta. She received the B.Eng degree in Biomedical Engineering from Universitas Airlangga, Indonesia, in 2013 and the M.Eng. degree in Electrical Engineering from Universitas Gadjah Mada, Indonesia in 2016. Her research interests include biomedical signal and image processing, computer vision and pattern recognition

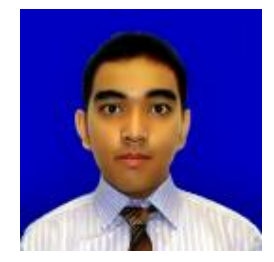

Dhimas Arief Dharmawan is a lecturer at the Department of Electrical Engineering, Faculty of Engineering, Universitas Muhammadiyah Yogyakarta. $\mathrm{He}$ received the B.Eng. degree in Electrical Engineering from Universitas Gadjah Mada, Yogyakarta, Indonesia in 2014. He is currently pursuing the Ph.D. degree in Electrical Engineering at Nanyang Technological University (NTU), Singapore. His research interests include image filtering and segmentation, machine learning, computer vision and pattern recognition. 